\title{
Biological Effect of Sucralose in Diabetic Rats
}

\author{
Helen N. Saada ${ }^{1}$, Nefissa H. Mekky ${ }^{2}$, Hassan A. Eldawy ${ }^{1}$, Abeer F. Abdelaal ${ }^{2}$ \\ ${ }^{1}$ Radiation Biology Department, National Center for Radiation Research and Technology, Atomic Energy Authority, Cairo, Egypt; \\ ${ }^{2}$ Zoology Department, Faculty of Sciences, Ain Shams University, Cairo, Egypt. \\ Email: helensaada@hotmail.com
}

Received March 12 $2^{\text {th }}, 2013$; revised April 15 ${ }^{\text {th }}, 2013$; accepted April 23 $3^{\text {rd }}, 2013$

Copyright (C) 2013 Helen N. Saada et al. This is an open access article distributed under the Creative Commons Attribution License, which permits unrestricted use, distribution, and reproduction in any medium, provided the original work is properly cited.

\begin{abstract}
Among people that might take a large amount of sucralose, are diabetic people who are attempting to modify their carbohydrate intake. The objective of this study is to evaluate the impact of sucralose; an artificial sweetener derived from sucrose, at a dose approximately twice the ADI on hyperglycemia, hyperlipidemia and oxidative stress in diabetic rats. Diabetes was induced in male albino rats after an intraperitoneal streptozotocin injection (65 mg/kg body weight). Animals with fasting blood glucose levels $\geq 250 \mathrm{mg} / \mathrm{dl}$ were considered diabetics. Sucralose was dissolved in water and administered to rats daily by oral gavages during a period of 6 weeks at a dose of $11 \mathrm{mg} / \mathrm{kg}$ body weight. Animals were divided into 4 groups and treated in parallel for 6 weeks. Control: rats received distilled water, Sucralose: rats received sucralose, Diabetic: diabetic rats received distilled water, Diabeticrats + Sucralose: diabetic rats received sucralose. The administration of sucralose to diabetic rats provoked a significant decrease $(P<0.05)$ of serum glucose and triglyceride levels, a significant increase $(P<0.05)$ of total cholesterol, low density lipoprotein-cholesterol (LDL-C), and high density lipoprotein-cholesterol (HDL-C), while has no effect $(P>0.05)$ on insulin, compared to their respective values in diabetic rats receiving distilled water. Biochemical analysis in brain and testis tissues showed that sucralose has no effect $(P>0.05)$ on superoxide dismutase (SOD), catalase, glutathione peroxidase (GSH-Px), and glucose-6-phosphate dehydrogenase (G-6-PDH) activities, and glutathione content (GSH), while reduced thiobarbituric acid reactive substances level (TBARS) $(P<0.05)$, compared to their respective values in diabetic rats receiving distilled water. It could be concluded that consumption of sucralose didn't induce oxidative stress, has no effect on insulin, reduce glucose absorption and intensify hypercholesterolemia in STZ-induced diabetic rats. Accordingly it is advised that diabetic people consuming high amount of sucralose must check their lipid profile to avoid diabetic complications.
\end{abstract}

Keywords: Sucralose; Diabetes; Antioxidants; Brain; Testis; Glucose; Lipids

\section{Introduction}

Diabetes mellitus, or simply diabetes, is a metabolic disease characterized by chronic hyperglycemia. There are two main types of Diabetes: Type I also called insulin-dependent diabetes (IDDM), is a severe, chronic form of diabetes caused by insufficient production of insulin and Type II also called non-insulin dependent diabetes (NIDDM) result from insulin resistance, a condition in which cells fail to use insulin properly and generally associated with pancreatic beta-cell dysfunction. Oxidative stress defined as an imbalance between oxidants and antioxidants plays an important role in the development of diabetic complications [1]. There are various mechanisms suggested to contribute to the formation of reactive oxygen species in diabetes.

Glucose oxidation is believed to be the main source of free radicals. In its enediol form, glucose is oxidized in a transition-metal dependent reaction to an enediol radical anion that is converted into reactive ketoaldehydes and to superoxide anion radicals that undergo dismutation to hydrogen peroxide. Hydrogen peroxide $\left(\mathrm{H}_{2} \mathrm{O}_{2}\right)$ in the presence of transition metals, can lead to production of extremely reactive hydroxyl radicals. Superoxide anion radicals can also react with nitric oxide to form reactive peroxynitrite radicals [2]. Hyperglycemia is also found to promote lipid peroxidation of low density lipoprotein (LDL) by a superoxide-dependent pathway resulting in the generation of free radicals [3]. Brownlee [4] demonstrated that hyperglycemia-induced generation of superoxide anion radicals at the mitochondrial level is the initial trigger of vicious cycle of oxidative stress in diabetes. Another important source of free radicals in diabetes is the interaction of glucose with proteins leading to the forma- 
tion of advanced glycation endproducts (AGEs), which activate the transcription factor NF- $\kappa \mathrm{B}$ and enhances production of nitric oxide, which is believed to be a mediator of islet beta cell damage [5].

Efficient defense and repair mechanisms exist in living cells to protect against oxidant species. Superoxide dismutase (SOD) catalyzes the dismutation of superoxide anion to hydrogen peroxide $\left(\mathrm{H}_{2} \mathrm{O}_{2}\right)$. Catalase serves to detoxify $\mathrm{H}_{2} \mathrm{O}_{2}$ by catalyzing a reaction between two $\mathrm{H}_{2} \mathrm{O}_{2}$ molecules, resulting in the formation of $\mathrm{H}_{2} \mathrm{O}$ and $\mathrm{O}_{2}$. In addition, catalase can promote the interaction of $\mathrm{H}_{2} \mathrm{O}_{2}$ with compounds that can serve as hydrogen donors so that the $\mathrm{H}_{2} \mathrm{O}_{2}$ can be converted to one molecule of $\mathrm{H}_{2} \mathrm{O}$, and the reduced donor becomes oxidized (a process sometimes called the peroxidatic activity of catalase) [6]. Glutathione Peroxidase/Glutathione Reductase system which includes the enzymes glutathione peroxidase (GSH$\mathrm{Px}$ ) and glutathione reductase and the co-factors reduced glutathione (GSH) and NADPH. Together, these molecules effectively remove $\mathrm{H}_{2} \mathrm{O}_{2}$ with formation of oxidized glutathione, which is recycled back to GSH by GSH-reductase, using the cofactor NADPH generated by glucose 6-phosphate dehydrogenase [7].

According to the International Diabetes Federation, percent of diabetes was $11.4 \%$ in the year 2010 and this likely to increase to $13.7 \%$ by the year 2030 . This alarmingly increasing incidence of diabetes encouraged the growth of the artificial sweetener industry. Sucralose, one of the newest artificial sweeteners has been approved by the Food and Drug Administration in 1998 and made available to the consumer under the trade name SPLENDA ${ }^{\circledR}$. Sucralose is obtained from sucrose where three hydroxylic groups, from positions 4,1 and 6 are replaced by 3 chlorine atoms to form the compound 4,1' and 6'trichlorogalacto-sacarose also known as 1,6-dichloro-1,6dideoxy- $\beta$-D fructo-furanosyl-4-chloro-4-deoxy- $\alpha$-D galacto-pyranoside [8]. In the European Union, it is also known under the E number E955. Sucralose is approximately 600 times as sweet as sucrose twice as sweet as saccharin, and 3.3 times as sweet as aspartame. The commercial success of sucralose-based products stems from its favorable comparison to other low-calorie sweeteners in terms of taste, stability, and safety [9]. According to Binns [10] it is stable in the presence of ethanol and able to be stored for more than one year while maintaining $99 \%$ of its original flavor. Its characteristics are preserved, even during pasteurization, sterilization and cooking at high temperatures. According to food and drug administration (FDA) the acceptable daily intake (ADI) for sucralose is $5 \mathrm{mg}$ per kilogram of body weight per day [11].

Studies performed on the metabolism of sucralose showed that when administered orally to mice at doses of 1000,1500 and $3000 \mathrm{mg} / \mathrm{kg}$ body weight/day, urinary elimination averaged, respectively $23 \%, 15 \%$ and $16 \%$, indicating that even with augmented administration of sucralose, there is no corresponding rise in absorption $[12,13]$. Studies indicate the existence of 2 hydrolysis products of sucralose, 4-chloro-4-deoxy-Dgalactose (4CG) and 1,6-dichloro-1-6-dideoxy-D-fructose (1,6-DCG) that are more rapidly absorbed after oral administration than the original sucralose compound. The hydrolysis product 4-CG is excreted, essentially in intact form, in the urine, while 1,6-DCF follows one of two principal metabolic pathways: reduction to 1,6 dichloroaminnitol, rapidly excreted in unaltered form in the urine, or conjugated with glutathione [14].

Studies investigating the safety of sucralose consumption revealed conflicting results [15]. It has no adverse effects on the central nervous system [16], immune system, reproductive performance $[17,18]$, and red blood cells constituents and morphology [19]. Conversely, some reports suggest sucralose is a possible trigger for some migraine patients [20]. A Duke University study, found evidence that sucralose limit the bioavailability of orally administered drugs [21]. However, an expert panel, reported the Duke study to be deficient in several critical areas that preclude reliable interpretation of the results [22]. Motwani et al. [23] reported that the reduced form of vitamin $B_{12}$ reacts readily with sucralosein an aqueous system to form an alkylcobalamin. Given the human consumption of sucralose from food and beverages, such a reaction could occur in vivo.

Among consumers that might take a large amount of sucralose, are diabetic people who are attempting to modify their carbohydrate intake. The objective of this study is to evaluate the impact of sucralose at a dose approximately twice the ADI on oxidative stress in the brain and testis of STZ-induced diabetic rats, besides its effect on serum glucose and insulin levels and lipid profile.

\section{Materials and Methods}

Male Sprague-Dawley rats (10 \pm 2 weeks old; 100 - 120 g) were purchased from the Egyptian Organization for Biological Products and Vaccines (Cairo, Egypt) and used for the different investigations carried out in the present study. Animals in specially designed cages, were maintained in conditions of good ventilation, normal temperatures and humidity ranges, and kept under observation for one week prior to experimentation. The rats received standard pellets, containing all nutritive elements (proteins, fats, carbohydrates, vitamins, salts and minerals). Drinking water and food were provided ad libitum throughout the study.

All animal procedures were performed in accordance with the Ethics Committee of the National Research Centre conformed to the "Guide for the care and use of 
Laboratory Animals" published by the National Institutes of Health (NIH publication No. 85-23, revised 1996).

\subsection{Induction of Diabetes}

Streptozotocin (STZ) was purchased from Sigma chemical company, St. Louis Missouri, USA, in the form of $1 \mathrm{~g}$ vials. Diabetes was induced by administering intraperitoneal injection of a freshly prepared solution of STZ (65 $\mathrm{mg} / \mathrm{kg} \mathrm{BW}$ ) in $0.1 \mathrm{M}$ cold citrate buffer ( $\mathrm{pH} 4.5)$ to the overnight fasted rats [1]. Since STZ is capable of producing fatal hypoglycemia as a result of massive pancreatic release of insulin, the rats were kept on $5 \%$ glucose for the next $24 \mathrm{hrs}$ to prevent hypoglycemia. Blood glucose levels were monitored using an Accu-check blood glucose meter (Roche Diagnostics, Basel, Switzerland) in tail vein $72 \mathrm{~h}$ after STZ administration. Rats with blood glucose levels $\geq 250 \mathrm{mg} / \mathrm{dl}$ were considered diabetics.

\subsection{Sucralose Treatment}

Sucralosewas obtained as SPLENDA ${ }^{\circledR}$ (McNeil Nutritionals, LLC, and Fort Washington, PA, USA) in the form of $1 \mathrm{~g}$ packets (yellow color). According to Northland Laboratories (Northbrook, IL), Splenda contents are sucralose $(1.10 \%)$, glucose $(1.08 \%)$, moisture $(4.23 \%)$, and maltodextrin (93.59\%). The content of each packet was dissolved in distilled water and administered to animals by oral gavages in a way that each animal received $1 \mathrm{ml}$ distilled water containing $11 \mathrm{mg}$ sucralose $/ \mathrm{Kg}$ body weight/day which is approximately twice the FDA accepted daily intake.

\subsection{Animal Groups}

Experimental animals were randomly divided into 4 groups of 10 rats each as follows: Control group: Normal healthy rats received distilled water during 6 weeks via gavages. Sucralose: Rats received sucralose during 6 weeks via gavages. Diabetic: diabetic rats received distilled water daily during 6 weeks via gavages, Diabetic + Sucralose: Diabetic rats received sucralose daily during 6 weeks via gavages.

\subsection{Biochemical Analysis}

The animals were sacrificed after a fasting period of 12 hours. Rats were anaesthetized with light ether and blood samples obtained via heart puncture by sterilized syringe. The blood was left to coagulate to obtain the serum after centrifugation at $1000 \mathrm{~g}$ for 15 minutes (K3 Centurion Scientific Ltd, London, UK).

Glucose content was determined following the method described by Trinder [24] using a T60 UV/VIS spectrophotometer, PG instruments, London, UK. Insulin concentration was determined using Radio-Immuno Assay device from “Axiom Veterinary Laboratories Ltd.", Germany. Serum lipid profile was assessed by the determination of triglycerides, total cholesterol, high density lipoprotein-cholesterol (HDL-C) and low density lipoprotein-cholesterol (LDL-C) levels. Triglycerideslevel was determined following the method described by Fossati and Prencipe [25]. Total cholesterol was determined following the method described by Richmond [26]. For the determination of HDL-C: the chylomicron fractions, LDL-C, and VLDL-C are precipitated quantitatively by phosphotungestic acid in the presence of magnesium ions. After centrifugation, the cholesterol concentration in the HDL fraction which remains in the supernatant was determined. LDL-C content was determined according to the Friedewald's [27] equation LDL-C $=$ TC $-($ HDL-C $-\mathrm{TG} / 5)$.

For the evaluation of antioxidant biomarkers a portion of brain and testis tissue was weighed and $10 \%$ weight/ volume tissue homogenate prepared in $0.1 \mathrm{M}$ phosphate buffer ( $\mathrm{pH}$ 7.4) using Teflon homogenizer (Glass-Col, Terre Haute, Ind., USA). The commercial kit from biodiagnostic Egyptian Company was used for the determination of superoxide dismutase (SOD) [28], catalase [29], glutathione peroxidase (GSH-Px) [30], and glucose-6phosphate dehydrogenase activities (G-6-PDH) [31], and glutathione (GSH) content [32] using a T60 UV/VIS spectrophotometer, PG instruments, London, UK.

\subsection{Statistical Analysis}

All values are presented as mean \pm S.E.M. All groups were compared by one-way analyses of variance (ANOVA) and post hoc multiple comparisons were done with Duncan test in SPSS/PC software program (version 12.0; SPSS Inc., Chicago, IL, USA) to determine the differences in all parameters. Differences were considered statistically significant at $P \leq 0.05$.

\section{Results}

The administration of sucralose to normal healthy rats provoked a significant decrease of $-14 \%$ of glucose level $(P<0.05)$ while has no effect on insulin level $(P>0.05)$. An increase of $20 \%$ for total cholesterol content $(P<$ $0.05), 25 \%$ for HDL-C content $(P<0.05), 38 \%$ for LDLC content $(P<0.01)$, and a decrease of $-17 \%$ for triglycerides content $(P<0.05)$ were recorded, regarding their respective values in the control group of rats receiving distilled water (Table 1).

In the diabetic group of rats glucose content showed an increase of $222 \%(P<0.001)$, while insulin content showed a decrease of $-25 \%(P<0.05)$, compared to their respective control values. Furthermore, the results showed an increase of $26 \%$ for total cholesterol content $(P<$ $0.05)$, a decrease of $-25 \%$ for HDL-C content $(P<0.05)$, 
an increase of $75 \%$ for LDL-C content $(P<0.001)$, and $98 \%$ for triglycerides content $(P<0.001)$, regarding their respective values in the control group (Table 1).

In the diabetic + sucralose group of rats glucose content showed an increase of $150 \%(P<0.001)$, while insulin content showed a decrease of $-22 \%(P<0.05)$, compared to their corresponding values in the control group receiving distilled water. The results showed an increase of $46 \%$ for total cholesterol content $(P<0.01)$, a decrease of $-14 \%$ for HDL-C content $(P<0.05)$, an increase of $138 \%$ for LDL-C content $(P<0.001)$, and an increase of $56 \%$ for triglycerides content $(P<0.01)$, regarding their corresponding values in the control group. Accordingly, it appears that the administration of sucralose to diabetic rats induced a decrease of glucose content $(P<0.001)$, while has no effect on insulin content $(P>0.05)$. Moreover, the administration of sucralose to diabetic rats induced an increase of total cholesterol content $(P<0.05)$, HDL-C content $(P<0.05)$, LDL-C content $(P<0.01)$, and induced a decrease of triglycerides content $(P<0.05)$, compared to their respective levels in the diabetic rats receiving distilled water (Table 1).

From the data in Tables 2 and $\mathbf{3}$ it is observed that the administration of sucralose to normal healthy rats has no effect on TBARS content, SOD, catalase, GSH-Px, and G-6-PDH activities and GSH content $(P>0.05)$ in the brain and testis, compared to their respective values in the control group receiving distilled water.

In the diabetic group of rats TBARS content showed an increase of $29 \%(P<0.05)$ in the brain and $22 \%(P<$ $0.05)$ in the testis, SOD activity an increase of $71 \%(P<$ $0.01)$ in the brain and $22 \%(P<0.05)$ in the testis, catalase activity showed no significant change $(P>0.05)$ in the brain and testis, GSH-Px activity showed an increase of $106 \%(P<0.001)$ in the brain and $122 \%(P<0.001)$ in the testis, G-6-PDH activity, an increase of $127 \%(P<$ $0.001)$ in the brain and $92 \%(P<0.01)$ in the testis and GSH content an increase of $24 \%(P<0.05)$ in the brain and $17 \%(P<0.05)$ in the testis, compared to their respective values in the control group (Tables 2 and 3).

In the diabetic + sucralose group of rats TBARS content showed an increase of $17 \%(P<0.05)$ in the brain and $12 \%(P<0.05)$ in the testis, SOD activity an increase of $65 \%(P<0.01)$ in the brain and $18 \%(P<0.05)$ in the testis, catalase activity showed no significant change $(P>0.05)$ in the brain and testis, GSH-Px activity, showed an increase of $100 \%(P<0.001)$ in the brain and $142 \%(P<0.001)$ in the testis, G-6-PDH activity, an increase of $123 \%(P<0.001)$ in the brain and $94 \%(P<$ $0.01)$ in the testis, and GSH content an increase of $29 \%$ $(P<0.05)$ in the brain and $19 \%(P<0.05)$ in the testis, compared to their respective values in the control group. Accordingly it appears that the administration of su-
Table 1. Effect of sucralose on some serum metabolites.

\begin{tabular}{|c|c|c|c|c|}
\hline $\begin{array}{r}\begin{array}{l}\text { Animal } \\
\text { groups }\end{array} \\
\text { Parameters }\end{array}$ & Control & Sucralose & Diabetic & $\begin{array}{l}\text { Diabetic + } \\
\text { Sucralose }\end{array}$ \\
\hline Glucose (mg/dl) & $100 \pm 4$ & $\begin{array}{c}86 \pm 7 \\
P<0.05^{\mathrm{a}}\end{array}$ & $\begin{array}{c}322 \pm 25 \\
P<0.001^{\mathrm{a}}\end{array}$ & $\begin{array}{l}250 \pm 30 \\
P<0.001^{\mathrm{a}} \\
P<0.001^{\mathrm{b}}\end{array}$ \\
\hline Insulin $(\mu \mathrm{IU} / \mathrm{ml})$ & $27 \pm 1.1$ & $\begin{array}{l}29 \pm 2.4 \\
P>0.05^{\mathrm{a}}\end{array}$ & $\begin{array}{c}20 \pm 1.1 \\
P<0.05^{\mathrm{a}}\end{array}$ & $\begin{array}{l}21 \pm 0.8 \\
P<0.05^{\mathrm{a}} \\
P>0.05^{\mathrm{b}}\end{array}$ \\
\hline $\begin{array}{l}\text { Total cholesterol } \\
\qquad(\mathrm{mg} / \mathrm{dl})\end{array}$ & $69 \pm 5.5$ & $\begin{array}{c}83 \pm 3.3 \\
P<0.05^{\mathrm{a}}\end{array}$ & $\begin{array}{l}87 \pm 7.0 \\
P<0.05^{\mathrm{a}}\end{array}$ & $\begin{array}{l}101 \pm 6.0 \\
P<0.01^{\mathrm{a}} \\
P<0.05^{\mathrm{b}}\end{array}$ \\
\hline HDL-C (mg/dl) & $40 \pm 3.2$ & $\begin{array}{l}50 \pm 2.0 \\
P<0.05^{\mathrm{a}}\end{array}$ & $\begin{array}{l}30 \pm 2.7 \\
P<0.05^{\mathrm{a}}\end{array}$ & $\begin{array}{l}34 \pm 2.6 \\
P<0.05^{\mathrm{a}} \\
P<0.05^{\mathrm{b}}\end{array}$ \\
\hline LDL-C (mg/dl) & $16 \pm 1.3$ & $\begin{array}{c}22 \pm 0.9 \\
P<0.01^{\mathrm{a}}\end{array}$ & $\begin{array}{c}28 \pm 2.3 \\
P<0.001^{\mathrm{a}}\end{array}$ & $\begin{array}{c}38 \pm 2.3 \\
P<0.001^{\mathrm{a}} \\
P<0.01^{\mathrm{b}}\end{array}$ \\
\hline $\begin{array}{l}\text { Triglycerides } \\
\text { (mg/dl) }\end{array}$ & $63 \pm 5.0$ & $\begin{array}{c}52 \pm 2.1 \\
P<0.05^{\mathrm{a}}\end{array}$ & $\begin{array}{c}125 \pm 9.9 \\
P<0.001^{\mathrm{a}}\end{array}$ & $\begin{array}{l}98 \pm 6.0 \\
P<0.01^{\mathrm{a}} \\
P<0.05^{\mathrm{b}}\end{array}$ \\
\hline
\end{tabular}

Each value represents the mean \pm standard error $(n=10)$; Means were compared by one-way analyses of variance (ANOVA) and post hoc multiple comparisons were done with Duncan test in SPSS/PC software program (version 12.0; SPSS Inc., Chicago, IL, USA) to determine the differences in all parameters; ${ }^{\mathrm{a}}$ Significance vs control group; ${ }^{\mathrm{b}}$ Significance vs diabetic group.

Table 2. Effect of sucralose on oxidant and antioxidant biomarkers in rat brain.

\begin{tabular}{|c|c|c|c|c|}
\hline $\begin{array}{c}\begin{array}{c}\text { Animal } \\
\text { groups }\end{array} \\
\text { Parameters }\end{array}$ & Control & Sucralose & Diabetic & $\begin{array}{l}\text { Diabetic }+ \\
\text { Sucralose }\end{array}$ \\
\hline $\begin{array}{c}\text { TBARS } \\
\text { (nmol/g tissue) }\end{array}$ & $1430 \pm 57$ & $\begin{array}{l}1426 \pm 71 \\
P>0.05^{\mathrm{a}}\end{array}$ & $\begin{array}{c}1845 \pm 102 \\
P<0.05^{\mathrm{a}}\end{array}$ & $\begin{array}{c}1673 \pm 107 \\
P<0.05^{\mathrm{a}} \\
P<0.05^{\mathrm{b}}\end{array}$ \\
\hline $\begin{array}{c}\text { SOD } \\
\text { (U/g tissue) }\end{array}$ & $172 \pm 7$ & $\begin{array}{c}160 \pm 6 \\
P>0.05^{\mathrm{a}}\end{array}$ & $\begin{array}{l}293 \pm 17 \\
P<0.01^{\mathrm{a}}\end{array}$ & $\begin{array}{l}284 \pm 12 \\
P<0.01^{\mathrm{a}} \\
P>0.05\end{array}$ \\
\hline $\begin{array}{c}\text { Catalase } \\
\text { (U/g tissue) }\end{array}$ & $83 \pm 9$ & $\begin{array}{c}85 \pm 10 \\
P>0.05^{\mathrm{a}}\end{array}$ & $\begin{array}{c}87 \pm 7 \\
P>0.05^{\mathrm{a}}\end{array}$ & $\begin{array}{c}89 \pm 10 \\
P>0.05^{\mathrm{a}} \\
P>0.05^{\mathrm{b}}\end{array}$ \\
\hline $\begin{array}{c}\text { GSH-Px } \\
\text { (mU/g tissue) }\end{array}$ & $78 \pm 5$ & $\begin{array}{c}79 \pm 4 \\
P>0.05^{\mathrm{a}}\end{array}$ & $\begin{array}{c}161 \pm 14 \\
P<0.001^{\mathrm{a}}\end{array}$ & $\begin{array}{c}156 \pm 15 \\
P<0.001^{\mathrm{a}} \\
P>0.05^{\mathrm{b}}\end{array}$ \\
\hline $\begin{array}{c}\text { G-6-PDH } \\
\text { (U/g tissue) }\end{array}$ & $2.35 \pm 0.12$ & $\begin{array}{c}2.47 \pm 0.24 \\
P>0.05^{\mathrm{a}}\end{array}$ & $\begin{array}{l}5.33 \pm 0.13 \\
P<0.001^{\mathrm{a}}\end{array}$ & $\begin{array}{c}5.24 \pm 0.30 \\
P<0.001^{\mathrm{a}} \\
P>0.05^{\mathrm{b}}\end{array}$ \\
\hline $\begin{array}{c}\text { GSH } \\
\text { (mg/g tissue) }\end{array}$ & $1.72 \pm 0.09$ & $\begin{array}{c}1.75 \pm 0.07 \\
P>0.05^{\mathrm{a}}\end{array}$ & $\begin{array}{c}2.13 \pm 0.16 \\
P<0.05^{\mathrm{a}}\end{array}$ & $\begin{array}{c}2.21 \pm 0.16 \\
P<0.05^{\mathrm{a}} \\
P>0.05^{\mathrm{b}}\end{array}$ \\
\hline
\end{tabular}

Each value represents the mean \pm standard error $(n=10)$; Means were compared by one-way analyses of variance (ANOVA) and post hoc multiple comparisons were done with Duncan test in SPSS/PC software program (version 12.0; SPSS Inc., Chicago, IL, USA) to determine the differences in all parameters; ${ }^{\mathrm{a}}$ Significance vs control group; ${ }^{\mathrm{b}}$ Significance vs diabetic group.

cralose to diabetic rats induced a significant decrease $(P$ $<0.05)$ of TBARS content in brain and testis. While has no effect $(P>0.05)$ on SOD, catalase, GSH-Px, and G- 
Table 3. Effect of sucralose on oxidant and antioxidant biomarkers in rat testis.

\begin{tabular}{|c|c|c|c|c|}
\hline $\begin{array}{c}\text { Animal } \\
\text { groups }\end{array}$ & Control & Sucralose & Diabetic & $\begin{array}{l}\text { Diabetic }+ \\
\text { Sucralose }\end{array}$ \\
\hline $\begin{array}{l}\text { TBARS }(\mathrm{nmol} / \mathrm{g} \\
\text { tissue) }\end{array}$ & $696 \pm 44$ & $\begin{array}{c}706 \pm 5 \\
P>0.05^{\mathrm{a}}\end{array}$ & $\begin{array}{l}846 \pm 100 \\
P<0.05^{\mathrm{a}}\end{array}$ & $\begin{array}{l}779 \pm 105 \\
P<0.05^{\mathrm{a}} \\
P<0.05^{\mathrm{b}}\end{array}$ \\
\hline SOD (U/g tissue) & $286 \pm 11$ & $\begin{array}{l}262 \pm 11 \\
P>0.05^{\mathrm{a}}\end{array}$ & $\begin{array}{l}349 \pm 20 \\
P<0.05^{\mathrm{a}}\end{array}$ & $\begin{array}{l}337 \pm 16 \\
P<0.05^{\mathrm{a}} \\
P>0.05^{\mathrm{b}}\end{array}$ \\
\hline $\begin{array}{c}\text { Catalase } \\
\text { (U/g tissue) }\end{array}$ & $181 \pm 10$ & $\begin{array}{l}186 \pm 11 \\
P>0.05^{\mathrm{a}}\end{array}$ & $\begin{array}{l}188 \pm 12 \\
P>0.05^{\mathrm{a}}\end{array}$ & $\begin{array}{c}194 \pm 7 \\
P>0.05^{\mathrm{a}} \\
P>0.05^{\mathrm{b}}\end{array}$ \\
\hline $\begin{array}{c}\text { GSH-Px } \\
\text { (mU/g tissue) }\end{array}$ & $88 \pm 6$ & $\begin{array}{c}84 \pm 5 \\
P>0.05^{\mathrm{a}}\end{array}$ & $\begin{array}{c}195 \pm 16 \\
P<0.001^{\mathrm{a}}\end{array}$ & $\begin{array}{c}234 \pm 20 \\
P<0.001^{\mathrm{a}} \\
P>0.05^{\mathrm{b}}\end{array}$ \\
\hline $\begin{array}{l}\text { G-6-PDH } \\
\text { (U/g tissue) }\end{array}$ & $2.67 \pm 0.20$ & $\begin{array}{c}2.72 \pm 0.40 \\
P>0.05^{\mathrm{a}}\end{array}$ & $\begin{array}{c}5.00 \pm 0.20 \\
P<0.01^{\mathrm{a}}\end{array}$ & $\begin{array}{c}5.17 \pm 0.50 \\
P<0.01^{\mathrm{a}} \\
P>0.05^{\mathrm{b}}\end{array}$ \\
\hline GSH (mg/g tissue) & $2.39 \pm 0.12$ & $\begin{array}{c}2.25 \pm 0.09 \\
P>0.05^{\mathrm{a}}\end{array}$ & $\begin{array}{c}2.79 \pm 0.21 \\
P<0.05^{\mathrm{a}}\end{array}$ & $\begin{array}{c}2.85 \pm 0.22 \\
P<0.05^{\mathrm{a}} \\
P>0.05^{\mathrm{b}}\end{array}$ \\
\hline
\end{tabular}

Each value represents the mean \pm standard error $(n=10)$; Means were compared by one-way analyses of variance (ANOVA) and post hoc multiple comparisons were done with Duncan test in SPSS/PC software program (version 12.0; SPSS Inc., Chicago, IL, USA) to determine the differences in all parameters; ${ }^{\mathrm{a}}$ Significance vs control group; ${ }^{\mathrm{b}}$ Significance vs diabetic group.

6PDH activities and GSH content, compared to their respective levels in the diabetic rats receiving distilled water (Tables 2 and 3).

\section{Discussion}

The impact of artificial sweeteners on human health is still a matter of controversial debate. Sucralose, a chlorinated sugar 600 times as sweet as sugar is widely used in beverages, frozen desserts, chewing gum, baked goods, and other foods. Safety concerns pertaining to sucralose revolve around the fact that it belongs to a class of chemicals called organochlorides, some types of which are toxic or carcinogenic; however, the presence of chlorine in an organic compound does not in any way ensure toxicity. In the current study, the administration of sucralose at a dose approximately twice the FDA accepted daily intake to diabetic rats provoked a significant decrease $(P<0.05)$ of serum glucose and triglyceride levels, a significant increase $(P<0.05)$ of total cholesterol, low density lipoprotein-cholesterol (LDL-C), and high density lipoprotein-cholesterol (HDL-C), while has no effect $(P>0.05)$ on insulin, compared to their respective values in diabetic rats receiving distilled water. Biochemical analysis in brain and testis tissues showed that sucralose has no effect $(P>0.05)$ on superoxide dismutase (SOD), catalase, glutathione peroxidase (GSH-Px), and glucose6-phosphate dehydrogenase (G-6-PDH) activities, and glutathione content (GSH), while reduced thiobarbituric acid reactive substances level (TBARS) $(P<0.05)$, compared to their respective values in diabetic rats receiving distilled water.

Diabetes mellitus is characterized by chronic hyperglycemia resulting from defects in insulin secretion, insulin action, or both. In the current study, diabetic rats showed a significant increase of glucose associated to a significant decrease of insulin, level, compared to their respective values in the control group. This could be explained by the fact that STZ induces degeneration in Langerhans islet beta cells [33-35]. The administration of sucralose to diabetic rats has no effect on insulin while reduces glucose level, compared to diabetic rats receiving distilled water. The results corroborate the findings that sucralose did not induce a cephalic insulin response [36]. Accordingly, it appears that the decrease of glucose might be attributed to a decrease in its absorption. Supporting our postulation Abou-Donia et al. [21] reported that the administration of sucralose at $1.1-11 \mathrm{mg} / \mathrm{kg}$ to male rats for 12-week's interfere with the absorption of nutrients and drugs. However, contrarily to our results, in vitro study revealed that sucralose induces insulin secretion by $\mathrm{Ca}^{2+}$ and cAMP-dependent mechanisms [37] and has no effect on the rate of glucose absorption [38]. Moreover, studies on diabetic patients (Type 1 and type 2) showed that the administration of $1000 \mathrm{mg}$ sucralose had no effect on plasma glucose [39], as well as, the administration of $7.5 \mathrm{mg} / \mathrm{kg} /$ day sucralose during 3-months' had no effect on glycated hemoglobin, and fasting plasma glucose in individuals with type 2 diabetes [40].

It is well documented that hyperlipidemia is a metabolic complication of diabetes $[41,42]$. In the current study, diabetic rats showed a significant increase of triglycerides, total cholesterol, and LDL-C levels associated to a significant decrease of HDL-C level, when compared to their respective values in the control group. The increase of cholesterol might result from increased intestinal absorption and synthesis [43] while the increase of triglycerides might be attributed to the inactivation of lipoprotein lipase resulting from insulin deficiency [44]. The administration of sucralose reduces the level of triglycerides while elevates the level of total cholesterol, LDL-C and HDL-C, when compared to their respective levels in rats receiving distilled water. The decrease of triglycerides might be attributed to the effect of sucralose on the peroxisome proliferator-activated receptors-alpha (PPAR- $\alpha$ ) thus increasing the expression of lipoprotein lipase. In addition, activation of PPAR- $\gamma$ in adipose tissue stimulates triglyceride storage [45]. The increase of HDL-C might result from the effect of sucralose on PPAR- $\alpha$ and activation of apo A-I and apo A-II [46]. However, contrarily, to the results obtained, previous studies demonstrated that administration of sucralose and its hydrolysis products, did not reveal sig- 
nificant alterations in the content of cholesterol [47].

Experimental evidence has considered the brain vulnerable to oxidative stress because of its high $\mathrm{O}_{2}$ utilization rate, its high content of polyunsaturated fatty acids, which are prone to lipid peroxidation, its high content of iron, which through the Fenton reactions increase the formation of free radicals [48]. The testis also has been reported as vulnerable to oxidative stress due to the abundance of highly unsaturated fatty acids (particularly 20:4 and 22:6) and the presence of potential reactive oxygen species (ROS)-generating systems [49]. The effect of diabetes on the antioxidant status is erratic, with no discernible pattern. For example, SOD activity has been reported to be decreased [50] or elevated [51] in the testis. Catalase activity is consistently found to be elevated in brain [52] of diabetic rats while decreased in the testis [51]. Glutathione concentration was found to be decreased [53] however, there is also some contradictory evidence of increased glutathione concentration in diabetic rat [54]. GSH-Px activity has been seen to be either elevated [55] or decreased [56] in the testis of STZ-induced diabetic rats.

Biochemical analysis in brain and testis tissues of diabetic rats revealed significant increase of TBARS levels with concomitant increase of SOD, GSH-Px and G-6$\mathrm{PDH}$ activities and GSH content, compared to their respective values in the control group. The increase in the activity of antioxidant enzymes might be a self response of the tissues towards the increase of free radicals generated by hyperglycemia. Supporting this postulation WeiChan et al. [57] recorded an increase of SOD gene expression in the brain of STZ-diabetic rats. Moreover, the results realize the concept that induction of oxidative stress induces mRNA species for SOD, and GSH-Px activities [58]. The administration of sucralose has no effect on the activity of antioxidants while slightly reduces the amount of TBARS. This unexpected effect might be attributed to one of its hydrolysis products, 1,6-dichloro-1-6-dideoxy-D-fructose (1,6-DCG) which undergoes reduction to 1,6 dichloroaminnitol before excretion [59].

According to the results obtained in the current study it could be concluded that excessive consumption of sucralose has no effect on oxidative stress and serum insulin level while interfere with glucose absorption and intensify hypercholesterolemia. Accordingly it is highly recommended that diabetic people consuming large amount of sucralose must follow their lipid profile to avoid diabetic complications.

\section{REFERENCES}

[1] A. Nakhaee, M. Bokaeian, A. Akbarzadeh and M. Hashemi, "Sodium Tungstate Attenuates Oxidative Stress in Brain Tissue of Streptozotocin-Induced Diabetic Rats," Biological Trace Element Research, Vol. 136, No. 2,
2010, pp. 221-231. doi:10.1007/s12011-009-8537-0

[2] B. Halliwell and J. M. Gutteridge, "Role of Free Radicals and Catalytic Metal Ions in Human Disease: An Overview," Methods in Enzymology, Vol. 186, 1990, pp. 1-85. doi:10.1016/0076-6879(90)86093-B

[3] M. Kawamura, J. W. Heinecke and A. Chait, "Pathophysiological Concentrations of Glucose Promote Oxidative Modification of Low Density Lipoprotein by a Superoxide Dependent Pathway," Journal of Clinical Investigation, Vol. 94, No. 2, 1994, pp. 771-778. doi:10.1172/JCI117396

[4] M. Brownlee, "Biochemistry and Molecular Cell Biology of Diabetic Complications," Nature, Vol. 414, No. 6865, 2001, pp. 813-820. doi:10.1038/414813a

[5] S. P. Wolff, Z. Y. Jiang and J. V. Hunt, "Protein Glycation and Oxidative Stress in Diabetes Mellitus and Ageing," Free Radical Biology and Medicine, Vol. 10, No. 5, 1991, pp. 339-352. doi:10.1016/0891-5849(91)90040-A

[6] M. Victor, J. Kenneth and R. Milagros, "Recent Progress in Pharmacological Research of Antioxidants in Pathological Conditions: Cardiovascular Health," Recent Patents on Anti-Infective Drug Discovery, Vol. 1, No. 1, 2006, pp. 17-31. doi:10.2174/157489106775244136

[7] J. Nordberg and E. S. J. Arner, "Reactive Oxygen Species, Antioxidants, and the Mammalian Thioredoxin System," Free Radical Biology and Medicine, Vol. 31, No. 11, 2001, pp. 1287-1312. doi:10.1016/S0891-5849(01)00724-9

[8] I. Knight, "The Development and Applications of Sucralose, a New High-Intensity Sweetener," Canadian Journal of Physiology and Pharmacology, Vol. 72, No. 4, 1993, pp. 435-439. doi:10.1139/y94-063

[9] M. A. Friedman, "Food Additives Permitted for Direct Addition to Food for Human Consumption; Sucralose," Federal Register: 21 CFR Part 172, Docket No. 87F-0086, 1998.

[10] N. M. Binns, "Sucralose: Alt Sweeteners and Light," Nutrition Bulletin, Vol. 29, No. 1, 2003, pp. 53-58. doi:10.1046/j.1467-3010.2003.00307.x

[11] Federal Register, "Food Additives Permitted for Direct Addition to Food for Human, Consumption: Sucralose," Food and Drug Administration, HHS, Final Rule April 3, 1998, Vol. 63, No. 64, Rules and Regulations, pp. 1641716433.

[12] B. A. John, S. G. Wood and D. R. Hawkins, "The Pharmacokinetics and Metabolism of Sucralose in the Mouse," Food and Chemical Toxicology, Vol. 38, No. 2, 2000, pp. 107-110. doi:10.1016/S0278-6915(00)00032-6

[13] A. B. Rodero, L. S. Rodero and R. Azoubel, "Toxicity of Sucralose in Humans: A Review," International Journal of Morphology, Vol. 27, No. 1, 2009, pp. 239-244. doi:10.4067/S0717-95022009000100040

[14] H. C. Grice and L. A. Goldsmith, "Sucralose: An Overview of the Toxicity Data," Food and Chemical Toxicology, Vol. 38, No. 2, 2000, pp. 1-6.

[15] L. A. Goldsmith, "Acute and Subchronic Toxicity of Sucralose," Food and Chemical Toxicology, Vol. 38, No. 2, 2000, pp. 53-69. doi:10.1016/S0278-6915(00)00028-4 
[16] J. P. Finn and G. H. Lord, "Neurotoxicity Studies on Sucralose and Its Hydrolysis Products with Special Reference to Histopathologic and Ultrastructural Changes," Food and Chemical Toxicology, Vol. 38, No. 2, 2000, pp. 7-17. doi:10.1016/S0278-6915(00)00024-7

[17] J. W. Kille, W. C Ford, P. McAnulty, J. M. Tesh, F. W. Ross and C. R. Willoughby, "Sucralose: Lack of Effects on Sperm Glycolysis and Reproduction in the Rat," Food and Chemical Toxicology, Vol. 38, No. 2, 2000, pp. 1929. doi:10.1016/S0278-6915(00)00025-9

[18] D. Brusick, V. L. Grotz, R. Slesinski, C. L. Kruger and A. W. Hayes, "The Absence Ofgenotoxicity of Sucralose," Food and Chemical Toxicology, Vol. 48, No. 11, 2010, pp. 3067-3072. doi:10.1016/j.fct.2010.07.047

[19] G. S. Rocha, M. O. Pereira, M. O. Benarroz, J. N. Frydman, V. C. Rocha, M. J. Pereira, A. S. Fonseca, A. C. Medeiros and M. Bernardo-Filho, "Sucralose Sweetener in Vivo Effects on Blood Constituents Radiolabeling, Red Blood Cell Morphology and Radiopharmaceutical Biodistribution in Rats," Applied Radiation and Isotopes, Vol. 69, No. 1, 2011, pp. 46-51. doi:10.1016/j.apradiso.2010.08.009

[20] R. M. Patel, R. Sarma and E. Grimsley, "Popular Sweetner Sucralose as a Migraine Trigger," Headache, Vol. 46, No. 8, 2006, pp. 1303-1304. doi:10.1111/j.1526-4610.2006.00543_1.x

[21] M. B. Abou-Donia, E. M. El-Masry, A. A. Abdel-Rahman, R. E. McLendon and S. S. Schiffman, "Splenda Alters Gut Microflora and Increases Intestinal p-Glycoprotein and Cytochrome p-450 in Male Rats," Journal of Toxicology and Environmental Health, Part A, Vol. 71, No. 21, 2008, pp. 1415-1429. doi:10.1080/15287390802328630

[22] D. Stephen, "Sucralose Safety Scientifically Sound," Expert panel, 2009. http://www.foodnavigator.com/Science-Nutrition/Sucralo se-safety-scientifically-sound-Expert-panel

[23] H. V. Motwani, S. Qiu, B. T. Golding, H. Kylin and M. Törnqvist, "Cob(I) Alamin Reacts with Sucralose to Afford an Alkylcobalamin: Relevance to in Vivo Cobalamin and Sucralose Interaction," Food and Chemical Toxicology, Vol. 49, No. 4, 2011, pp. 50-57. doi:10.1016/j.fct.2010.11.037

[24] P. Trinder, "Enzymatic Colorimetric Determination of Glucose," Annals of Clinical Biochemistry, Vol. 6, No. 2, 1969, pp. 24-27.

[25] P. Fossati and L. Prencipe, "Serum Triglycerides Determination Colometrically with an Enzyme Produce Hydrogen Peroxide," Clinical Chemistry, Vol. 28, No. 10, 1982, p. 2077.

[26] N. Richmond, "Colorimetric Determination of Total Cholesterol and High Density Lipoprotein Cholesterol (HDLC)," Clinical Chemistry, Vol. 19, No. 12, 1973, pp. 13501356.

[27] W. T. Friedewald, R. I. Levy and D. S. Frederickson, "Estimation of the Concentration of Low-Density Lipoprotein Cholesterol in Plasma, without Use of the Preparative Ultracentrifuge," Clinical Chemistry, Vol. 18, No. 6, 1972, pp. 449-452.
[28] M. Nishikimi, N. A. Rao and K. Yagi, "The Occurrence of Superoxide Anion in the Reaction of Reduced Phenazinemethosulfate and Molecular Oxygen," Biochemical and Biophysical Research Communications, Vol. 46, No. 2, 1972, pp. 849-854. doi:10.1016/S0006-291X(72)80218-3

[29] H. U. Aebi, “Catalase,” In: H. U. Bergmeyer, Ed., Methods in Enzymatic Analysis, 2nd Edition, Vol. 3, Academic Press, New York, 1983, pp. 276-286.

[30] D. E. Paglia and W. N. Valentine, "Studies on the Quantitative and Qualitative Characterization of Erythrocyte Glutathione Peroxidase," Journal of Laboratory and Clinical Medicine, Vol. 70, No. 1, 1967, pp. 158-169.

[31] A. Kornberg and B. L. Horecker, "Glucose-6-Phosphate Dehydrogenase," In: S. Colowick and N. Kaplan, Eds., Methods in Enzymology. I, Academic Press Inc., New York, 1955, pp. 323-325. doi:10.1016/0076-6879(55)01046-X

[32] E. Beutler, O. Duron and B. M. Kelly, "Improved Method for Determination of Blood Glutathione," Journal of Laboratory and Clinical Medicine, Vol. 61, No. 5, 1963, p. 882.

[33] A. Akbarzadeh, D. Norouzian, M. R. Mehrabi, Sh. Jamshidi, A. Farhangi, A. Allah Verdi, S. M. A. Mofidian and R. B. Lame, "Induction of Diabetes by Streptozotocin in Rats," Indian Journal of Clinical Biochemistry, Vol. 22, No. 2, 2007, pp. 60-64. doi:10.1007/BF02913315

[34] S. R. F. Tabatabaei, A. A. Papahn, M. R. Jalali and L. Rahimi, "The Effects of Oral Vitamin E on Induction and Consequence of Experimental Diabetes Mellitus in Rats," Pakistan Journal of Biological Sciences, Vol. 11, No. 4, 2008, pp. 633-637. doi:10.3923/pjbs.2008.633.637

[35] T. K. Bera, D. De, K. Chatterjee, K. M. Ali and D. Ghosh, "Effect of Diashis, a Polyherbal Formulation, in Streptozotocin-Induced Diabetic Male Albino Rats," International Journal of Ayurveda Research, Vol. 1, No. 1, 2010, pp. 18-24. doi:10.4103/0974-7788.59939

[36] H. E. Ford, V. Peters, N. M. Martin, M. L. Sleeth, M. A. Ghatei, G. S. Frost and S. R. Bloom, "Effects of Oral Ingestion of Sucralose on Gut Hormone Response and Appetite in Healthy Normal-Weight Subjects," European Journal of Clinical Nutrition, Vol. 65, No. 4, 2011, pp. 508-513. doi:10.1038/ejen.2010.291

[37] Y. Nakagawa, M. Nagasawa, S. Yamada, A. Hara, H. Mogami, V. O. Nikolaev, M. J. Lohse, N. Shigemura, Y. Ninomiya and I. Kojima, "Sweet Taste Receptor Expressed in Pancreatic $\beta$-Cells Activates the Calcium and Cyclic AMP Signaling Systems and Stimulates Insulin Secretion," PLoS ONE, Vol. 4, No. 4, 2009, p. 5106. doi:10.1371/journal.pone.0005106

[38] J. Ma, J. Chang, H. L. Checklin, R. L. Young, K. L. Jones, M. Horowitz and C. K. Rayner, "Effect of the Artificial Sweetener, Sucralose, on Small Intestinal Glucose Absorption in Healthy Human Subjects," British Journal of Nutrition, Vol. 104, No. 6, 2010, pp. 803-806. doi:10.1017/S0007114510001327

[39] N. H. Mezitis, C. A. Maggio, P. Koch, A. Quddoos, D. B. Allison and F. X. Pi-Sunyer, "Glycemic Effect of a Single High Oral Dose of the Novel Sweetener Sucralose in Patients with Diabetes," Diabetes Care, Vol. 19, No. 9, 
1996, pp. 1004-1005. doi:10.2337/diacare.19.9.1004

[40] V. L. Grotz, R. R. Henry, J. B. McGill, M. J. Prince, H. Shamoon, J. R. Trout and F. X. Pi-Sunyer, "Lack of Effect of Sucralose on Glucose Homeostasis in Subjects with Type 2 Diabetes," Journal of the American Dietetic Association, Vol. 103, No. 12, 2003, pp. 1607-1612. doi:10.1016/j.jada.2003.09.021

[41] J. D. Mendez and F. Balderas, "Regulation of Hyperglycemia and Dyslipidemia by Exogenous L-Arginine in Diabetic Rats," Biochimie, Vol. 83, No. 5, 2001, pp. 453458. doi:10.1016/S0300-9084(00)01192-5

[42] O. Komolafe, D. Adeyemi, S. Adewole and E. Obuotor, "Streptozotocin-Induced Diabetes Alters the Serum Lipid Profiles of Adult Wistar Rats," The Internet Journal of Cardiovascular Research, Vol. 7, No. 1, 2009, p. 2.

[43] D. Mathe, "Dyslipidemia and Diabetes Animal Models," Diabetes \& Metabolism, Vol. 21, No. 2, 1995, p. 106.

[44] C. F. Semenkovich, M. Wims, L. Noe, J. Etienne and L. Chan, "Insulin Regulation of Lipoprotein Lipase Activity in 3T3-L1 Adipocytes Is Mediated at Posttranscriptional and Posttranslational Levels," Journal of Biological Chemistry, Vol. 25, No. 15, 1989, pp. 9030-9038.

[45] P. Ferré, "The Biology of Peroxisome Proliferator-Activated Receptors. Relationship with Lipid Metabolism and Insulin Sensitivity," Diabetes, Vol. 53, No. 1, 2004, pp. 43-50. doi:10.2337/diabetes.53.2007.S43

[46] J. C. Fruchart, B. Staels and P. Duriez, "PPARs, Metabolic Disease and Atherosclerosis," Pharmacological Research, Vol. 44, No. 5, 2001, pp. 345-352. doi:10.1006/phrs.2001.0871

[47] I. M. Baird, N. W. Shephard, R. J. Merritt and G. HildickSmith, "Repeated Dose Study of Sucralose Tolerance in Human Subjects," Food and Chemical Toxicology, Vol. 38, No. 2, 2000, pp. 123-129. doi:10.1016/S0278-6915(00)00035-1

[48] B. Halliwell, "Role of Free Radicals in the Neurodegenerative Diseases: Therapeutic Implications for Antioxidant Treatment," Drugs \& Aging, Vol. 18, No. 9, 2001, pp. 685-716. doi:10.2165/00002512-200118090-00004

[49] R. C. Zangar, D. R. Davydov and S. Verma, "Mechanisms That Regulate Production of Reactive Oxygen Species by Cytochrome P450," Toxicology and Applied Pharmacology, Vol. 199, No. 3, 2004, pp. 316-331. doi:10.1016/j.taap.2004.01.018

[50] S.-Y. Ou, G. M. Jackson, X. Jiao, J. Chen, J.-Z. Wu and X.-S. Huang, "Protection against Oxidative Stress in Diabetic Rats by Wheat Bran Feruloyl Oligosaccharides," Journal of Agricultural and Food Chemistry, Vol. 55, No. 8, 2007, pp. 3191-3195. doi:10.1021/jf063310v

[51] A. Armagan, UzEfkan, H. R. Yilmaz, S. Soyupek, T.
Oksay and N. Ozcelik, "Effects of Melatonin on Lipid Peroxidation and Antioxidant Enzymes in Streptozotocin-Induced Diabetic Rat Testis," Asian Journal of Andrology, Vol. 8, No. 5, 2006, pp. 595-600. doi:10.1111/j.1745-7262.2006.00177.x

[52] M. Aragno, E. Tamagno, V. Gatto, E. Brignardello, S. Parola, O. Danni and G. Boccuzzi, "Dehydroepiandrosterone Protects Tissues of Streptozotocin-Treated Rats against Oxidative Stress," Free Radical Biology \& Medicine, Vol. 26, No. 11-12, 1999, pp. 1467-1474. doi:10.1016/S0891-5849(99)00012-X

[53] M. H. Abdel-Wahab and A. R. Abd-Allah, "Possible Protective Effect of Melatonin and/or Desferrioxamine against Streptozotocin-Induced Hyperglycaemia in Mice," Pharmacological Research, Vol. 41, No. 5, 2000, pp. 533-537. doi:10.1006/phrs.1999.0614

[54] D. Borenshtein, R. Ofri, M. Werman, A. Stark, H. J. Tritschler, W. Moeller and Z. Madar, "Cataract Development in Diabeticsand Rats Treated with $\alpha$-Lipoic Acid and Its $\gamma$-Linolenic Acid Conjugate," Diabetes/Metabolism Research and Reviews, Vol. 17, No. 1, 2001, pp. 4450.

doi:10.1002/1520-7560(0000)9999:9999<::AID-DMRR1 $\underline{53>3.0 . \mathrm{CO} ; 2-\mathrm{S}}$

[55] H. G, Zhao, G. W. Liu, S. C. Liu, Z. C. Wang, Y. Liu, Z. Q. Wang, C. Li, L. Cai and S. L. Gong, "Changes of Cycle and Apoptosis of Spermatogenic Cells and Antioxidant Capacity in Male Rats with Diabetes Mellitus," $\mathrm{Na}$ tional Journal of Antrology, Vol. 11, No. 10, 2005, pp. 735-739.

[56] G. Ricci, A. Catizone, R. Esposito, F. A. Pisanti, M. T. Vietri and M. Galdieri, "Diabetic Rat Testes: Morphological and Functional Alterations," Andrologia, Vol. 41, No. 6, 2009, pp. 361-368. doi:10.1111/j.1439-0272.2009.00937.x

[57] W.-C. Huang, S.-W. Juang, M. Liu, T.-C. Chi and J.-T. Cheng, "Changes of Superoxide Dismutase gene Expression and Activity in the Brain of Streptozotocin-Induced Diabetic Rats," Neuroscience Letters, Vol. 275, No. 1, 1999, pp. 25-28.

[58] P. Kaur, G. Kaur and M. P. Bansal, "Tertiary-Butyl Hydroperoxide Induced Oxidative Stress and Male Reproductive Activity in Mice: Role of Transcription Factor NF-KappaB and Testicular Antioxidant Enzymes," Reproductive Toxicology, Vol. 22, No. 3, 2006, pp. 479-484. doi:10.1016/j.reprotox.2006.03.017

[59] H. C. Grice and L. A. Goldsmith, "Sucralose: An Overview of the Toxicity Data," Food and Chemical Toxicology, Vol. 38, No. 2, 2000, pp. 1-6. doi:10.1016/S0278-6915(00)00023-5 